\title{
THE CONFINED COMPRESSIVE STRENGTH OF POLYCRYSTALLINE ICE
}

\author{
By STEPHEN J. Jones \\ (Snow and Ice Division, National Hydrology Research Institute, Department of Environment, \\ Ottawa, Ontario K1A 0E7, Canada).
}

\begin{abstract}
Triaxial tests were carried out on randomly oriented, laboratory-made, polycrystalline ice, between strain-rates of $10^{-7}$ and $10^{-1} \mathrm{~s}^{-1}$ and with confining pressures from 0.1 to $85 \mathrm{MN} \mathrm{m}^{-2}$, at $-11 \pm 1^{\circ} \mathrm{C}$. Below strain-rates of about $10^{-5} \mathrm{~s}^{-1}$ the confining pressure has little effect, but at higher strain-rates the confining pressure prevents cracking which allows the compressive strength to rise to a value greater than the unçonfined compressive strength. At $1.4 \times 10^{-2} \mathrm{~s}^{-1}$, the unconfined strength of $12 \mathrm{MN} \mathrm{m}^{-2}$ rises to $26 \mathrm{MN} \mathrm{m}^{-2}$ with a confining pressure of $25 \mathrm{MN} \mathrm{m}^{-2}$, before dropping slowly with greater confining pressures. Above $10^{-2} \mathrm{~s}^{-1}$ the unconfined strength decreases rapidly with increasing strain-rate, but the confined strength continues to increase. The dependence of strain-rate on the maximum compressive stress is discussed.
\end{abstract}

RÉSUMÉ. Résistance à la compression en enceinte confinée de la glace polycristalline. On décrit des essais au triaxal de glaces polycristallines produites en laboratoire à orientation quelconque des cristaux, entre des vitesses de $10^{-7}$ et $10^{-1} \mathrm{~s}^{-1}$ et avec des pressions en enceinte fermée de $0,1 \dot{a} 85 \mathrm{MN} \mathrm{m}^{-2} \dot{\mathrm{a}}-11 \pm 1^{\circ} \mathrm{C}$. Pour des vitesses de déformation inferieures à environ $10^{-5} \mathrm{~s}^{-1}$, la pression dans l'enceinte a une faible influence, mais à des vitesses plus élevées la pression de l'enceinte empêche la fissuration, permettant à la résistance à la compression d'atteindre une valeur plus grande que sans confinement. A $1,40 \times 10^{-2} \mathrm{~s}^{-1}$, la résistance qui est de $12 \mathrm{MN} \mathrm{m}^{-2}$ sans confinement, atteint $26 \mathrm{MN} \mathrm{m}^{-2}$ sous une pression de confinement de $25 \mathrm{MN} \mathrm{m}^{-2}$ avant de croître doucement avec des pressions de confinement plus fortes. Au dessus de $10^{-2} \mathrm{~s}^{-1}$ la résistance sans confinement décroît rapidement si augmente la vitesse de déformation, mais la résistance avec confinement continue à croître. On discute l'influence de la vitesse de déformation sur l'effort maximum de compression que la glace peut encaisser.

ZuSAMMENFASSUNG. Die beschränkte Druckfestigkeit polykristallinen Eises. Es werden drei-axiale Versuche an zufällig orientiertem, künstlich hergestelltem polykristallinem Eis bei Deformationsraten von $10^{-7}$ bis $10^{-1} \mathrm{~s}^{-1}$ und mit beschränkten Drucken von 0,1 bis $85 \mathrm{MN} \mathrm{m}^{-2}$ bei $-11 \pm 1^{\circ} \mathrm{C}$ beschrieben. Bei Deformationsraten unter ca. $10^{-5} \mathrm{~s}^{-1}$ hat der Beschränkungsdruck nur geringen Einfluss; bei höheren Deformationsraten jedoch verhindert er ein Zerspringen, weil dann die Druckfestigkeit höher wird als im unbeschränkten Zustand. Bei $1,4 \times$ $10^{-2} \mathrm{~s}^{-1}$ steigt die unbeschränkte Festigkeit von $12 \mathrm{MN} \mathrm{m}^{-2}$ auf $26 \mathrm{MN} \mathrm{m}^{-2}$ unter einem Beschränkungsdruck von $25 \mathrm{MN} \mathrm{m}^{-2}$; mit wachsendem Beschränkungsdruck nimmt sie langsam wieder ab. Über $10^{-2} \mathrm{~s}^{-1}$ sinkt die unbeschränkte Festigkeit schnell mit wachsender Deformationsrate, die beschränkte Festigkeit jedoch nimmt weiter zu. Die Abhängigkeit der Deformationsrate von der maximalen Druckfestigkeit wird diskutiert.

\section{INTRODUCTION}

Many workers have studied the uniaxial mechanical behaviour of ice but few have bothered with more complicated stress systems, even though most engineering, and glacier-flow, situations involve complex stress fields. Rigsby (1958) studied the effect of hydrostatic pressure on the shear creep behaviour of four single crystals and concluded that if the temperature was measured from the pressure-melting point, hydrostatic pressure had no effect on the creep strain-rate. In other words, the creep strain-rate was increased by the hydrostatic pressure, at constant temperature. Haefeli and others (1968) deformed three polycrystalline ice samples in compressive creep with a $30 \mathrm{MN} \mathrm{m}^{-2}$ superimposed hydrostatic pressure and they also showed that the creep-rate was increased by the hydrostatic pressure. At higher strain-rates, comparable to those used in the present study, Goughnour and Andersland (1968) noticed a slight increase in the strength of pure ice samples with a confining pressure of $0.7 \mathrm{MN} \mathrm{m}^{-2}$. Simonson and others ([ $\left.\left.{ }^{\mathrm{c}} 1975\right]\right)$ conducted triaxial tests on both ice and a sand-ice mixture up to $200 \mathrm{MN} \mathrm{m}^{-2}$ at $-10^{\circ} \mathrm{C}$ and found a "monotonic decrease in strength to the highest pressure tested". There have been several studies on various sand-ice and permafrost systems (Chamberlain and others, 1972; Alkire and Andersland, 1973; Smith and Cheatham, 1975; Parameswaran, 1980; Parameswaran and Jones, 1981). The object of this work was to study the effect of confining pressure on the compressive behaviour of ice over a wide range of strain-rates, from the normal 
creep range to the brittle fracture range. This paper reports all the results obtained at $-11 \pm 1^{\circ} \mathrm{C}$, in the strain-rate range $10^{-7}$ to $10^{-1} \mathrm{~s}^{-1}$. Preliminary data were given in Jones (1978).

\section{SAMPLE PREPARATION}

Details of the method of sample preparation were given in Jones (1978). Random polycrystalline samples with grain-size less than $1.0 \mathrm{~mm}$ diameter were produced; these had a density of $0.913 \pm 0.001 \mathrm{Mg} \mathrm{m}^{-3}$ at $-10^{\circ} \mathrm{C}$ which indicates the presence of some air bubbles. These bubbles were too small to be seen individually with the naked eye but gave the ice a slightly hazy appearance. Figure 1 shows a typical thin section through crossed polaroids. The average grain diameter of this sample is $0.8 \mathrm{~mm}$ as determined by counting the number of intercepts of grain boundaries with a single straight line. The sample dimensions for the mechanical tests were $20 \mathrm{~mm}$ diameter by $60 \mathrm{~mm}$ long. Stainless-steel caps were frozen onto both ends of the ice, using a special jig to maintain alignment of the sample and end caps. These end caps prevented any sideways motion of the ice sample while it was in the testing machine.

\section{METHOD}

Details of the high-pressure cell and general method of testing are given in Jones (1978). In brief, the ice was deformed at a constant strain-rate (strictly constant rate of deformation) in compression on an Instron model 1116 tester with a superimposed hydrostatic pressure of up to $85 \mathrm{MN} \mathrm{m}^{-2}$. For comparison, unconfined tests were carried out at atmospheric pressure $\left(0.1 \mathrm{MN} \mathrm{m}^{-2}\right)$. For strain-rates less than $5 \times 10^{-3} \mathrm{~s}^{-1}$ the load-time curve was recorded on the Instron chart recorder. Above this strain-rate the load was recorded on a galvanometric type recorder (Kyowa Electronic Instrument Co. Rapicorder RMV-300E) which had a much faster response time than the standard Instron chart recorder. Jones (1978) explains the precautions that were necessary, and the method by which the load-time curves were converted to truestress-true-strain curves.

\section{Results AND DISCUSSION}

Figure 2 shows some of the stress-strain data obtained at a strain-rate of $5.5 \times 10^{-3} \mathrm{~s}^{-1}$. The stress plotted in Figure 2 is the differential stress i.e. $\sigma_{1}-\sigma_{3}$, the amount by which the axial stress

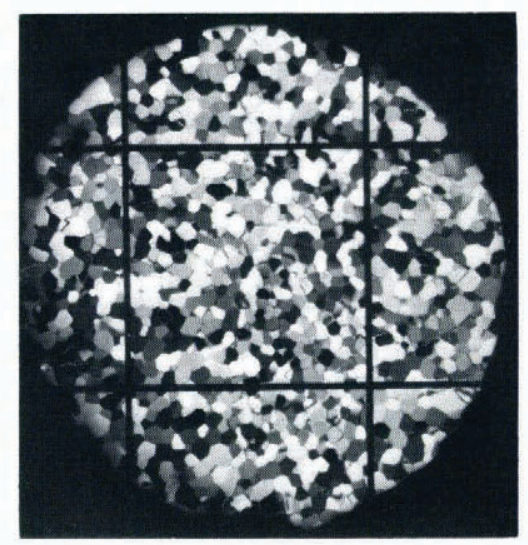

Fig. 1. A typical thin section viewed through crossed polaroids. A $1 \mathrm{~cm}$ grid is shown and the mean grain diameter of this sample, as determined by the intercept method, is $0.8 \mathrm{~mm}$. 


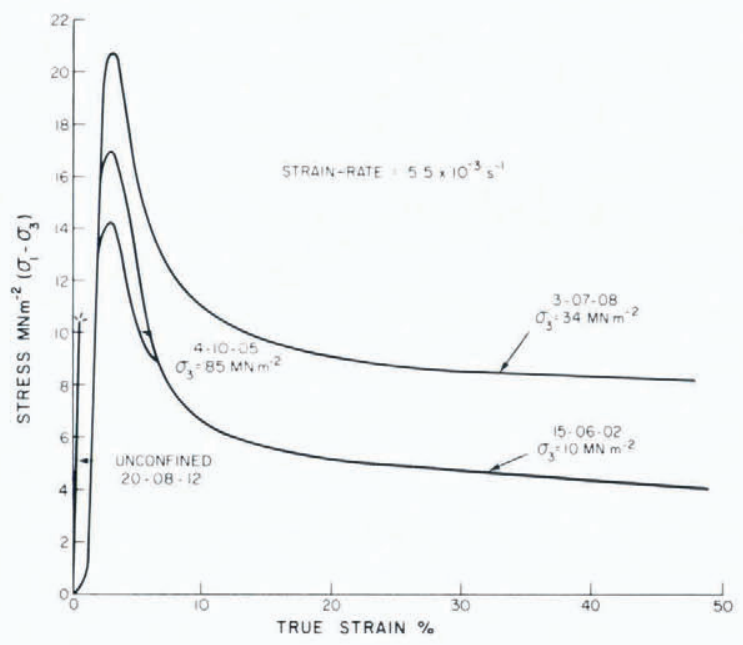

Fig. 2. True stress-true strain curves of polycrystalline ice for various confining pressures $\sigma_{3}$. All tests were carried out at $-11^{\circ} \mathrm{C}$. Sample numbers are shown (e.g. 20-08-12).

departs from the confining pressure. At this strain-rate the unconfined test gave an elastic deformation followed by brittle failure, as shown in the Figure. The application of a $10 \mathrm{MN} \mathrm{m}^{-2}$ confining pressure suppressed this brittle failure and the associated cracking, and allowed the stress to rise much higher than in the unconfined test, leading to plastic yielding and flow. The yield stress, or strength, thus defined, was greater for confining pressures of $34 \mathrm{MN} \mathrm{m}^{-2}$, but for higher confining pressures the strength value fell, as shown by the curve for an $85 \mathrm{MN} \mathrm{m}^{-2}$ confining pressure in Figure 2. If these yield stresses, or brittle failure stresses, as the case may be, are then plotted against confining pressure, curves such as those shown in Figure 3 are obtained for different strain-rates. As can be seen by comparing these curves, the effect of the confining pressure at low strain-rates is much less than that at high strain-rates. This is because, at low strain-rates, the ice deforms plastically in the unconfined tests, as well as in the confined ones, with little or no cracking. At high strain-rates the confining pressure is needed to suppress the cracking which would otherwise lead to failure.

Figure 3 also shows that at the high strain-rates, the rise in strength with confining pressure is rapid, with the bulk of the increase occurring in the first $10 \mathrm{MN} \mathrm{m}^{-2}$ confining pressure, whereas the decrease in strength after the maximum is reached is relatively gradual. At the low strainrates $\left(\approx 10^{-6} \mathrm{~s}^{-1}\right)$ the maximum is reached at a confining pressure of about $10-20 \mathrm{MN} \mathrm{m}^{-2}$ whereas at the high strain-rates $\left(\approx 10^{-3} \mathrm{~s}^{-1}\right)$ the peak occurs at about $40 \mathrm{MN} \mathrm{m}^{-2}$. However, there is too much scatter in the data to determine the exact dependence of peak strength on confining pressure. For a temperature of $-11^{\circ} \mathrm{C}$, the melting point would be reached at a confining pressure of about $100 \mathrm{MN} \mathrm{m}^{-2}$, above which the strength would have to be zero.

This decrease in strength with increasing confining pressure, after the maximum has been reached, is probably due to an increase in the amount of liquid at the grain-boundary junctions. Barnes and others (1971) have shown that above $-10^{\circ} \mathrm{C}$ grain-boundary sliding and the presence of liquid at the triple junctions of the grain boundaries serve primarily as accommodation processes for the high stresses generated by basal glide within the grains. In the present experiment the confining pressure causes a lower melting point so that more triplejunction melting occurs, and hence a lower stress is required to maintain the deformation rate. If this is so, we would not expect to see the same softening if the tests were conducted at temperatures of $-20^{\circ} \mathrm{C}$ or lower at the same confining pressures, because triple-junction melting is not thought to be significant below $-10^{\circ} \mathrm{C}$. 

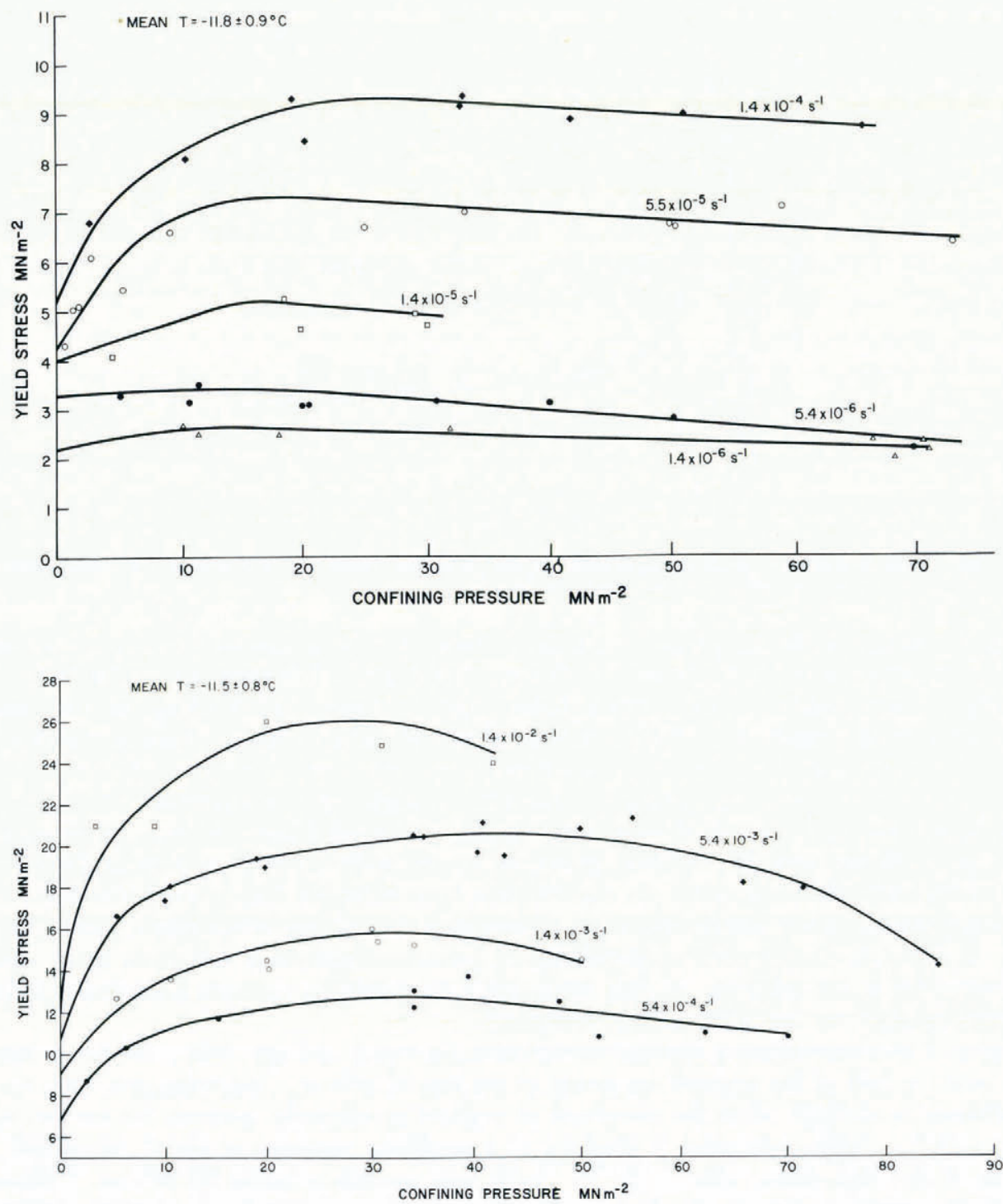

Fig. 3. Yield, or maximum, stress plotted against confining pressure for different strain-rates, as marked. The individual data points for the unconfined tests are not shown, for clarity, but the point of intersection of the drawn curve with the vertical axis is the mean of the unconfined tests. The number of such tests varied from 3 to 17 , as shown in Figure 4.

The peak strength obtained at each strain-rate, from curves such as those shown in Figure 3, was plotted as a function of strain-rate, as shown in Figure 4. The unconfined, atmosphericpressure results are also shown for comparison. The confined strengths are always greater than the unconfined, but the two sets of data converge clearly at low strain-rates. At high strain-rates, above $10^{-2} \mathrm{~s}^{-1}$, the unconfined strengths decrease rapidly, whereas the confined strengths continue to increase, although the rate of increase with confining pressure is less. However, this latter result may be an artefact of the experiment because at high speeds (greater than $1.4 \times 10^{-2} \mathrm{~s}^{-1}$ ) the load capacity of the Instron testing machine was limited to $5000 \mathrm{~kg}$, which 


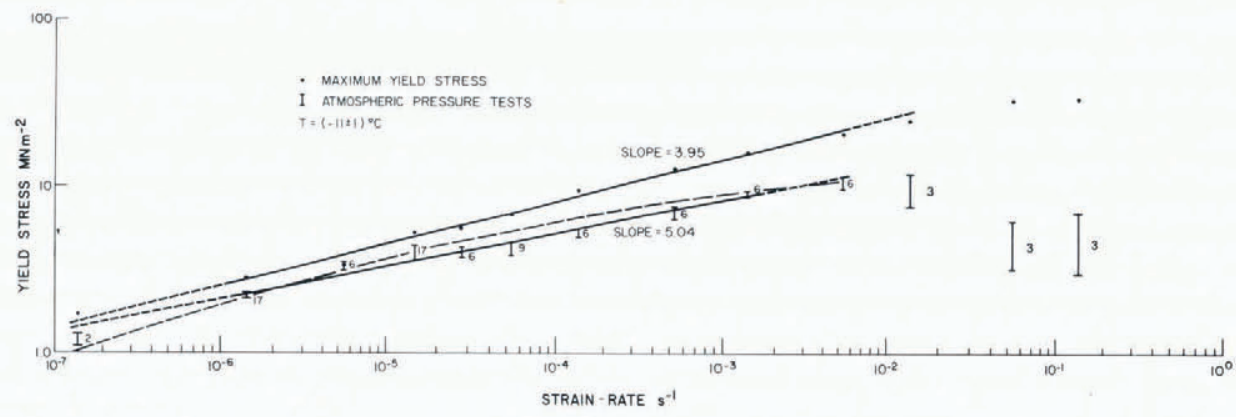

Fig. 4. Yield, or failure, stress for the unconfined, or atmospheric pressure, tests, and the maximum yield stress obtained in the confined tests such as shown in Figure 3, plotted against strain-rate. The unconfined data points are shown as the standard deviation of all the results obtained at that particular strain-rate; the number of unconfined samples tested is shown beside the standard deviation.

in turn limited the confining hydrostatic pressure to $50 \mathrm{MN} \mathrm{m}^{-2}$, and it is possible that a larger confining pressure would have given a greater strength than that shown in Figure 4. However, there is certainly no decrease in strength in the confined tests above $10^{-2} \mathrm{~s}^{-1}$.

Two straight lines and one curve, have been drawn on Figure 4 . The straight lines are the best fit to the unconfined and confined data for strain-rates between $10^{-6}$ and $10^{-3} \mathrm{~s}^{-1}$. The data for lower strain-rates are less accurate because only a few tests were carried out, and at higher strain-rates the data clearly deviate from a straight line, as discussed above. A straightline relationship on the double logarithmic scale of Figure 4 implies $\dot{\varepsilon} \propto \sigma^{n}$ where $n$ is the slope of this line. For the confined tests $n=3.95$ and for the unconfined tests $n=5.04$. This value of 5.04 for the unconfined tests is in agreement with other workers at high strain-rates (Ramseier, 1976), who has analyzed his results in a similar way. The curved line drawn on Figure 4 was generated using the equation of Barnes and others (1971):

$$
\dot{\varepsilon}=A^{\prime}(\sinh \alpha \sigma)^{n} \exp (-Q / R T)
$$

and using mean values of $A^{\prime}\left(2.58 \times 10^{10} \mathrm{~s}^{-1}\right), \alpha\left(0.266 \mathrm{MN}^{-1} \mathrm{~m}^{2}\right), n(3.02)$, and $Q\left(78.1 \mathrm{~kJ} \mathrm{~mol}^{-1}\right)$ derived from their creep results between $-8^{\circ} \mathrm{C}$ and $-45^{\circ} \mathrm{C}$. The curve is, therefore, not a best fit to my data but, rather, it shows that the present unconfined constant strain-rate data agree very well with the Barnes and others constant-stress results. This supports the idea of a correspondence principle outlined by Hooke and others (1980). It also shows that it is largely a matter of personal preference whether one uses a power law or a hyperbolic sine law to express empirically the dependence of stress on strain-rate, at least over this range of strain-rates.

At low strain-rates below about $10^{-6} \mathrm{~s}^{-1}$, where there is no cracking evident, most workers have found $n$ to be nearer to 3. My value for the confined tests 3.95 falls half-way between this and my value of 5.04 for the unconfined tests. Since the two straight lines converge at low strainrates - and even cross if, in creep, hydrostatic pressure increases the flow rate slightly (Rigsby, 1958; Haefeli and others, 1968) - it is not possible for the $n$-value of the unconfined tests to be less than the $n$-value for the confined tests. Therefore, at such low strain-rates, the $n$-value for unconfined tests will not fall below 3.95, unless the confined tests also give an $n$ less than 3.95 in this strain-rate range.

Although a straight line has been drawn through the unconfined data of Figure 4, it can be seen that between the strain-rates of $10^{-5}$ and $10^{-4} \mathrm{~s}^{-1}$ there appears to be a "plateau" in which the stress increases very little. Many tests were carried out specifically in this strain-rate range, as shown by the numbers on Figure 4, and this "plateau" seems genuine. The Instron machine speed was checked and was correct. No other workers have commented on this "plateau" and the reason for it is not clear. It does not mark the transition from no-cracking to cracking in the 
ice, since this occurs at a lower strain-rate (between $10^{-7}$ and $10^{-6} \mathrm{~s}^{-1}$ ). There does not appear to be a similar plateau in the confined tests.

Above $5 \times 10^{-3} \mathrm{~s}^{-1}$, the unconfined tests show a dramatic reduction in strength with further increase in strain-rate, whereas the confined strength continues to increase. This reduction in unconfined strength is due to a combination of two effects. First, end effects at high strain-rates are important (Hawkes and Mellor, 1970) and slight irregularities in the flatness of the ends or in the alignment of the end caps can cause stress concentrations and lead to premature cracking and failure. However, because ice is a relatively soft material, this may not be so important as the second factor, which is that the Instron testing machine itself is not infinitely rigid. This leads to the release of strain energy stored in the machine when the test specimen reaches the limit of its resistance. The loading platens accelerate violently and the sample is destroyed. When there is a confining pressure present, it acts as a stiffening element on the testing machine and this may be the reason why the confining pressure tests in Figure 4 do not show a reduction in strength at the high strain-rates (Sinha and Frederking, 1979). Also, other workers, Michel (1978), have observed the reduction in unconfined compressive strength beginning at a strain-rate of about $5 \times 10^{-4} \mathrm{~s}^{-1}$, rather than the value of $10^{-2} \mathrm{~s}^{-1}$ found here. This is, presumably, because their testing machine was less rigid, and their end effects more important, than in this study. It is reasonable to expect that another study, using a more rigid testing machine, would not show the reduction until even higher stresses were reached.

As mentioned earlier, the samples contained a small amount of air, about $0.6 \%$ by volume. At $-11^{\circ} \mathrm{C}$ and confining pressures above $10.5 \mathrm{MN} \mathrm{m}^{-2}$ this will form a clathrate structure within the ice. Such clathrates are thought to occur in the deep Antarctic ice (Miller, 1969). If the mechanical properties of this air clathrate had been very different from those of ice, we might have seen a significant change in yield stress at a confining pressure of about $10 \mathrm{MN} \mathrm{m}^{-2}$. However, no such change was noticed in Figures 3 and 4, from which we conclude that a small amount of air clathrate does not significantly affect the flow of ice. We intend to carry out a further study on the effect of air bubbles on the strength of ice.

MS. received 1 September 1980 and in revised form 6 November 1980

\section{REFERENCES}

Alkire, B. D., and Andersland, O. B. 1973. The effect of confining pressure on the mechanical properties of sand-ice materials. Journal of Glaciology, Vol. 12, No. 66, p. 469-81.

Barnes, P. and others. 1971. Friction and creep of polycrystalline ice, by P. Barnes, D. Tabor, and J. C. F. Walker. Proceedings of the Royal Society of London, Ser. A, Vol. 324, No. 1557, p. 127-55.

Chamberlain, E., and others. 1972. The mechanical behaviour of frozen earth materials under high pressure triaxial test conditions, [by] E. Chamberlain, C. Groves, and R. Perham. Géotechnique (London), Vol. 22, No. 3, p. 469-83.

Goughnour, R. R., and Andersland, O. B. 1968. Mechanical properties of a sand-ice system. Journal of the Soil Mechanics and Foundations Division, American Society of Civil Engineers, Vol. 94, No. SM4, p. 923-50.

Haefeli, R., and others. 1968. Deformation of polycrystalline ice under combined uniaxial and hydrostatic pressure, [by] R. Haefeli, C. Jaccard, and M. [R.] de Quervain. Union de Géodésie et Géophysique Internationale. Association Internationale d'Hydrologie Scientifique. Assemblee générale de Berne, 25 sept.-7 oct. 1967. [Commission de Neiges et Glaces.] Rapports et discussions, p. 341-44. (Publication No. 79 de l'Association Internationale d'Hydrologie Scientifique.)

Hawkes, I., and Mellor, M. 1970. Uniaxial testing in rock mechanics laboratories. Engineering Geology, Vol. 4, No. 3, p. $177-285$.

Hooke, R. L., and others. 1980. Mechanical properties of polycrystalline ice: an assessment of current knowledge and priorities for research, [by] R. L. Hooke [and 9 others]. Cold Regions Science and Technology, Vol. 3, No. 4, p. $263-75$.

Jones, S. J. 1978. Triaxial testing of polycrystalline ice. Proceedings of the third International Conference on Permafrost, July 10-13,1978, Edmonton, Alberta, Canada, Vol. 1, p. 670-74.

Michel, B. 1978. Ice mechanics. Québec, Les Presses de l'Université Laval.

Miller, S. L. 1969. Clathrate hydrates of air in Antarctic ice. Science, Vol. 165, No. 3892, p. 489-90.

Parameswaran, V. R. 1980. Deformation behaviour and strength of frozen sand. Canadian Geotechnical Journal, Vol. 17, No. 1, p. 74-88. 
Parameswaran, V. R., and Jones, S. J. 1981. Triaxial testing of frozen sand. Journal of Glaciology, Vol. 26, No. 95, p. $147-55$.

Ramseier, R. O. 1976. Growth and mechanical properties of river and lake ice. Ottawa, Dept. of the Environment. Marine Sciences and Information Directorate. (Manuscript Report Series, No. 40.)

Rigsby, G. P. 1958. Effect of hydrostatic pressure on velocity of shear deformation of single ice crystals. Journal of Glaciology, Vol. 3, No. 24, p. 271-78

Simonson, E. R., and others. ['1975.] High pressure mechanical properties of three frozen materials, [by] E. R. Simonson, A. H. Jones, and S. J. Green. Proceedings of the fourth International Conference on High Pressure, Kyoto, 1974 (Kyoto, Physico-Chemical Society of Japan), p. 115-21.

Sinha, N. K., and Frederking, R. M. W. 1979. Effect of test system stiffness on strength of ice. POAC 79. The fifth International Conference on Port and Ocean Engineering under Arctic Conditions. At the Norwegian Institute of Technology. August 13-18, 1979. Proceedings, Vol. 1, p. 708-17.

Smith, L. L., and Cheatham, J. B., jr. 1975. Plasticity of ice and sand-ice systems. Transactions of the American Society of Mechanical Engineers. Journal of Engineering for Industry, Vol. 97, Ser. B, No. 2, p. 479-84. 